\title{
PLAYING SIMPLE GRAMMAR GAME AS AN ALTERNATIVE WAY TO HELP PRIMARY SCHOOL STUDENTS IMPROVE THEIR GRAMMAR
}

\author{
Hendrikus Male \\ hendrikus.male@uki.ac.id \\ Universitas Kristen Indonesia
}

\begin{abstract}
This paper explores the teaching of grammar to foreign young learners. It is aimed at giving some insight to teachers specifically to private English teachers encompassing primary young learner, simple grammar game, and teaching grammar to young learner. This article also provides information of how to conduct simple grammar game in EFL class. Although it is still debatable concerning the teaching of grammar to young learners, teachers should provide fun and interesting activities to teaching it to their pupils. Therefore, it is crucial as the English teacher in teaching grammar to young learners in order to help them recognize adequate number of basic knowledge or language skills in their level. In order to bridge the gap, simple grammar game could be used as a natural way to help and lead them to the understanding of the grammar that they may put and make use of it into their real life context in learning English.
\end{abstract}

Keywords: Grammar, Primary Young Learners, Language Skills

\section{ABSTRAK}

Makalah ini membahas pengajaran tatabahasa Inggris kepada anak-anak Sekolah Dasar dengan tujuan untuk memberikan masukan kepada para guru khususnya untuk guru bahasa Inggris yang mencakup anak-anak Sekolah Dasar, permainan tatabahasa sederhana, dan tata bahasa pengajaran dalam anak-anak Sekolah Dasar. Artikel ini juga memberikan informasi bagaimana cara menjalankan permainan tatabahasa sederhana di kelas bahasa Inggris. Meski masih bisa diperdebatkan mengenai pengajaran tatabahasa kepada anak-anak Sekolah Dasar, guru diharapkan untuk memberikan kegiatan yang menyenangkan dan menarik untuk mengajarkannya kepada murid-muridnya. Oleh karena itu, sangat penting bagi guru bahasa Inggris dalam mengajarkan tatabahasa kepada anak-anak Sekolah Dasar sehingga membantu siswa/i dalam mengenali pengetahuan dasar atau kemampuan bahasa yang memadai di 
Male, Playing Simple Grammar Game as an Alternative Way to Help Primary School Students Improve Their Grammar

tingkat mereka. Untuk menjembatani kesenjangan tersebut, permainan tatabahasa dapat digunakan sebagai salah satu cara alami untuk membantu dan mengarahkan anak-anak Sekolah Dasar dalam memahami tata bahasa yang mungkin dapat dimasukkan dan gunakan ke dalam konteks kehidupan nyata mereka dalam mempelajari bahasa Inggris.

Kata Kunci: Permainan Tatabahasa, anak-anak Sekolah Dasar, Pengetahuan Dasar

\section{INTRODUCTION}

English subject has been removed in Indonesia national curriculum specifically for primary level. The government recommended the subject be one of the local content in state school. Not like in state schools, English is still taught in primary level even from kindergarten in many private schools. In the context of English as a foreign language, the teaching of English to young learner may be taught differently from the native. This is because the language is not used in everyday context. The foreign young learner may not be familiar with English or new language. Besides, children in the country where English is not used may find it difficult with the language. They also begin to learn new or foreign language at different ages. They also have weaknesses and strengths. Some may learn the language very fast and the other may learn it slowly. In addition, they may prefer to learn English based on their own preferences of learning style. Yet, teaching English to young learners may need an extensive knowledge of teaching methods or strategies teachers should have since it is fundamental to make the learners be more familiar with grammar or other language skills.

Primary school students are categorized as young learners. Scott and Ytreberg (1990) have divided young learners into two groups, children under seven, specifically, the five to seven years old, belong to the first group. Slattery and Willis (2006) called this 
Male, Playing Simple Grammar Game as an Alternative Way to Help Primary School Students Improve Their Grammar

group as "very young learners". The second group - young learners are the eight to ten years old or children between eight and twelve. (Slattery \& Willis, 2006). Since learners have differences among them in terms of what they can do, teachers then have to be aware of the characteristics of certain age of children, what they really need in the learning activities such as the methods or the learning style, or other aspects involving the children's participation.

Slattery and Willis (2006) said that children of different ages can perform different things. There are a number of abilities that they can do at their own level. For example:

Very young learners:

a) learn through hearing real English, the same ways as they learn their native language

b) learn through actions, games, playing, they learn new words naturally c) learn through sounds, playing with words and phrases, songs

d) like having fun and need not to be aware of learning a foreign language

e) usually cannot read and write, so they need to learn new words through talk and games

f) are not able to understand grammatical rules, they need to hear lots of English, words and phrases so that their grammar will develop on its own

g) Children between seven and twelve:

h) usually can read and write or are in process of learning it

i) develop their ability to think

j) are becoming aware of the real worlds and the world of fantasy

k) are able to plan and do the activity in the best way

I) can work with others and learn from others 
m) are aware of the importance of reliability and responsibility for the whole class activities

n) are able to make the most of reading books in English

o) can understand very simple explanation about how language works

p) are able to experiment with language, working with language creatively

q) can help teacher with organization of activities (Slattery \& Willis, 2006)

According to Slattery and Willis (2006) young children have typical characteristics, they:

a. are developing very quickly as individuals

b. learn in variety of ways, by watching, listening, imitating, doing things

c. are not able to understand grammatical rules and explanations about language

d. try to make sense of situations by making use of non-verbal clues e. talk in their mother tongue about what they understand and do - this helps them learn

f. can generally imitate the sounds they hear quite accurately and copy the way adults speak

g. are naturally curious

h. love to play and use their imagination

i. are comfortable with routines and enjoy repetition

j. have quite a short attention span and so need variety

Concerning the young learners, the paper merely focuses on the young learners who are in primary schools. Although they have been introduced English for few years, they may not be able to create and use their own set of learning strategies due to the limitation of the language and age ability. Therefore, it is necessary for teachers to create a number of strategies or techniques in teaching 
Male, Playing Simple Grammar Game as an Alternative Way to Help Primary School Students Improve Their Grammar

as solutions to help them cope with certain topics appropriately.

Grammar as Basic Knowledge of Language

In studying the language, learners are also encountered with the basic knowledge of the language such as grammar and vocabulary. In the teaching of grammar, teachers should understand their learners' potential ability comprehensively before deciding it to teach in a traditional way or to include it contextually. "In genuine communication beyond the classroom, grammar and context are often so closely related that appropriate grammatical choices can only be made with reference to the context and purpose of the communication" (Nunan, 1998, p.102). "Some advantages of this method are, students are exposed to the target language in an authentic or near authentic setting, they see or hear the target language before having to focus on it" (Riddell, 2003, p.46).

Moreover, the teaching of grammar in context will help learners improve either their writing or communication skills. As Harmer (1991, p.57) pointed out that "Students need to get an idea of how the new language is used by native speakers and the best way of doing this is to present language in context". Ellis (2006, p. 84) affirmed that

"Grammar Teaching involves any instructional technique that draws learners' attention to some specific grammatical form in such a way that it helps them either to understand it metalinguistically and / or process it in comprehension and / or production so that they can internalize it".

Morelli (2003, as citied in AlMekhlafi \& Nagaratnam, 2011, p. 72) states that, "Grammar can be taught traditionally or contextually, but student perception should be considered by teachers in the decision-making process." As one of 
the basic knowledge, the study of language rules to change words into sentences normally deals with grammar. Thornbury (1999, p. 1) defined that "Grammar is partly the study of what forms (or structures) are possible in a language. Thus, grammar is a description of the rules that govern how a language's sentences are formed" Harmer (1987, p. 1) stated that "The grammar of a language is what happens to words when they become plural or negative, or what word order is used when we make questions or join two clauses to make one sentence." According to Scrivener (2003),

grammar is not just a dry list of facts and rules. It is in our heads and it is a living resource that gives us the ability to communicate our ideas and feelings and to understand what other people say or write to us.

Ur (1988, p. 4) also defined grammar as "the way language manipulates and combine words (or bits of words) in order to form longer units of meanings". Questions then may be raised whether or not young learners must study the grammar in order to be fluent in their communication. The answer is that young learners may or may not have to study grammar depending on the needs of the young learners or the teachers are knowledgeable to teaching the grammar to them. Besides, in general most people around the world in their childhood speak their mother tongue without studying the grammar. They even start to speak the language and ignore the grammar. It is suggested that when the children group up or become adult learners they have to study the grammar as it is essential in a way of learning the language faster and more efficiently. This is in line with Povjakalová (2012) who stated that Grammar is essential language skill and it is important for learning foreign language.

\section{Teaching Grammar to Young Learners}

The teaching of grammar in EFL context is traditionally 
Male, Playing Simple Grammar Game as an Alternative Way to Help Primary School Students Improve Their Grammar

dominated by Grammar Translation method in which the teachers use their mother tongue in order to help the learners understand better the language they are learning. However, in teaching and learning English to young learners, it is different from adults even though young learners are good in absorbing new language. The following are recommendations to teachers in teaching English to young learners: 1) Teaching grammar in context; the teaching of grammar must be put in a context whenever teaching it to young learner. So, they may have a lot of opportunities to use it in their real life situation. 2) Teaching grammar minimally; it means that the teaching of grammar must not be given with all the complex rules or regulation, instead teaching it simply and minimally. This is in line with (Scott and Ytreberg, 1990) stating that "Teachers, of course, should be aware of grammar and structures that they want their pupils to know. But they should teach just a minimum of grammar and what is important, the older pupils only." Dendrinos (2017) states that "children build hypotheses about how the foreign language works from the input they have received during their limited experience with the language. Therefore, their errors can give teachers useful information about their learning processes and their internal grammars."

In addition to teaching grammar to young learners, Scrivener (2003) proposed that grammar teaching includes a few stages that young learners have to experience before being able to use a new grammar item. They need to pay attention to the grammar item in presentation; the presentation should be clear which means that there should not be any difficulties in understanding, they should understand the text. Next, it should be efficient, which means that young learners should use the new grammar in an organized way. They are also asked to use a new language effectively resulting in a 
enjoyable learning. This also means that the students will be encouraged and motivated to learn. Next, it should be appropriate, meaning that the language used has to be proper. The last, it should be productive which means that the pupils should be allowed to create their own sentences and questions using the grammar they have already learned. (see, Harmer, 1998).

Harmer (1998) further stated that all characteristics can be well achieved through the following activities: using charts, texts, stories, songs and rhymes, dialogues, and visuals for situations. This is in line with Dendrinos (2017) states that "songs, arts and crafts and activities which involve children in using the language can help assess learners' understanding and use of grammar. " Dendrinos (2017) further stated that "children learn best by playing, singing, and using language in real situations and for fun, NOT by explanation." Even though it may not be easy for the pupils to learn a new structure for the first time, it is believed that the more times pupils are exposed to the structure, they will understand more to using it. Teachers should plan activities which the learners can use as many grammar items as possible (Scrivener, 2003).

In summary, in teaching grammar to young learners, teachers should provide many ways or techniques to improve the learners' skills. In addition, the more basic language skills young learners master, the easier it is for him/her to communicate and understand English itself.

Teaching Grammar through Games to Young Learners

As stated earlier in Introduction Section that the teaching of grammar to young learners is not the same to adults due to the lack of attention and ability to absorb the abstract concept are not similar to one another even though both adults and young learners share the same physical figures. Moreover, young 
Male, Playing Simple Grammar Game as an Alternative Way to Help Primary School Students Improve Their Grammar

learners tend to have a very short time span in the sense that in a certain topic, they cannot concentrate for a long time compared to adults. To bridge the gap, games can be as solution to overcome the obstacles faced by young learners.

Additionally, games can accommodate the learners' desires to learn something in a fun and enjoyable way and yet elicit much experience out of it. Another reason is that young learners enjoy activities involving much fun while they are learning. However, not all games are suitable to teach young learners. For example, if the games are merely for fun and not connected to educational goals, it may not and work out well.

There are many kinds of games that the teacher may use to improve teaching grammar such as Guessing Game, Hangman and etc. Those games may not only function as time filler but as part of learning and teaching activities. The following is the example of game that the writer created and used to use when teaching grammar to young learners.

Name of game: simple grammar

Length of time: $15-20$ minutes

Grade of students: 4-6

Level: Elementary

Objectives: Young learners are able to write a simple sentence in the form of statements, negatives or questions.

\section{Procedure (Rules):}

1) The teacher groups the students into three groups. (for example, Group A, B and C). Each group consists of 5-6 students.

2) Each group sits in the circle of their group

3) As each group is ready, the teacher starts to read the rules and play the game. E.g (to the teacher) for first round, Group $A, B$ and $C$, please write down something you like for example starting with I like apples. She likes apples

4) For second round, Group A, B, and $\mathrm{C}$, write down things you 
don't like. For example I don't like Banana

5) For third round, Group A, B, and $\mathrm{C}$, write down things you would like to know from your friends what they like. For example, do you like mango?

6) Each group has to wait for the teacher's instruction to start writing in a specific given time simultaneously.

7) After finishing three rounds, the teacher asks the students to exchange their result among the groups.

8) If each group has the same sentence, then the sentence is not counted. However if it is different, it must be counted as points

9) The group that has the most different sentences would be the winner.

\section{Round A}

Having done with the first sentence by the first person. The first person has to pass to the next person in their group to start a new sentence, and so on until the last person's turn.

The duration for the first round is 23 minutes.

If they still have time they may continue writing new sentence as much as possible.

\section{Round B}

The activity is the same like round $A$ but the second round focus on negative sentence

\section{Round C}

The activity is similar to round A or $B$ but the third round focuses on questions.

The simple grammar game is designed to help the young learners to be able to improve their writing and speaking skills. Why it is called simple grammar because the topic or sentence is simple and easy and it can be simply changed with others' simple topic for example I like apples can be altered with I am happy and so on. Additionally, why it is suggested to teach grammar using games since there can be a lot of fun and young learners prefer to have interesting learning activities 
Male, Playing Simple Grammar Game as an Alternative Way to Help Primary School Students Improve Their Grammar

in which they can actively engage in the learning and activities process. Henceforth, learning English by playing games is worth implementing in order to improve the learners' language skills specifically grammar. Hence, it can become one of the solutions to avoid boredom in learning the grammar. It is also hoped that the primary teachers can use it in their class whenever they teach the grammar.

\section{CONCLUSION}

In the context of English as a foreign language, the teaching of grammar to young learners may not be easy. Apart from its debatable argument whether young learner should be taught grammar or not, it

\section{REFERENCES}

Adamson, R. (2009). Retrieved July 12, 2014, from http://www.educ.ualberta.ca/s taff/olenka.Bilash/best\%20of $\% 20$ bilash/inductivedeductive .html is highly suggested that the teacher should be creative in teaching their students. The key is the teacher him/herself in creating fun atmosphere or enjoyable teaching and learning activities. Teachers are also hoped to use the grammar as much as possible and put it into real life context so that the young learners may learn and practice the use of grammar effectively and efficiently and the most important thing is that teacher can vary their teaching and learning activities by using games so that young learners may not feel bored and enjoy each activities given to them as well as using the grammar knowledge into their real life situation appropriately.

Al-Mekhlafi, A. M., \& Nagaratnam, R. P. (2011). Difficulties in teaching and learning grammar in an EFL context. International Journal of Instruction, IV(2), 69-92.

Brown, D. (2006). Teaching by principles. Eaglewood Clifs, NJ: Prentice Hall. 
Brown, H. D. (1987). Principles of language learning and teaching. Englewoods Cliffs: Prentice Hall.

Dendrinos, B. (2017, June 12). ELT Methods and Practices.

Retrieved from http://opencourses.uoa.gr/co urses/ENL4/

Ellis, R. (2006). Current issues in the teaching of grammar: An SLA perspective. TESOL QUARETERLY, 83-107.

Hammond, R. (1988). Accuracy versus communicative competency: The acquisition of grammar in the second language classroom. Hispania, 408-417.

Harmer, J. (1987). Teaching and learning grammar. London: Longman.

Harmer, J. (1991). The practice of English language teaching. London: Longman.

Huang, J. (2010). Grammar instruction for adult English language learner: A taskbased learning framework. Journal of Adult Education, XXXIX(1), 29-37.

Karshen, S. (1985). The input hypothesis: issues and implication. London: Longman.

Larsen-Freeman, D. (2003). Teaching language from grammar to grammaring. Canada: Heinle.

Long, M. H. (1991). "Focus on form: A design feature in language teaching methodology". In K. De Bot, R. B. Ginsberg, \& C. Kramsch, Foreign language research in cross cultural perspective (pp. 39-52). Amsterdam: John Benjamins.

Nunan, D. (1998). Teaching grammar in context. ELT Journal, 52(2), 101-109.

Pazaver, A., \& Wang, H. (2009). Asian students' perceptions of grammar teaching in the ESL classroom. The International Journal of Language Society and Culture, 27-35.

Pica, T. (2000). Tradition and transistion in English language teaching methodology. System, 1-18.

Povjakalová, A. (2012). Teaching grammar to young learners using interactive whiteboard (Master Thesis). Brno: Masaryk University.

Prince, M. J., \& Felder, R. M. (2006). Inductive teaching and learning methods: Definitions, comparisons, and the research bases. J. Engr. Education, 123-138.

Richards, J. C. (2001). Curicullum development in language 
Male, Playing Simple Grammar Game as an Alternative Way to Help Primary School Students Improve Their Grammar

teaching. Cambridge:

Cambridge University Press.

Riddell, D. (2003). Teaching English as a foreign language. London: Hodder Education.

Rutherford, W. E. (1987). Second language grammar: Learning and teaching. New York: Longman.

Rutherford, W., \& Smith, M. S. (1988). Grammar and second language teaching: A book of readings. New York:

Heinle\&Heinle.

Scott, W. A., \& Ytreberg, L. H. (1990). Teaching English to children. London: Longman.

Scrivener, J. (2003). Teaching grammar. Oxford: Oxford University Press.
Slattery, M., \& Willis, J. (2006).

English for primary teachers. Oxford: Oxford University Press.

Spada, N., \& Lightbown, P. (1999). Instruction, first language influence, and developmental readiness in second language acquisition. The Modern Language Journal(83), 1-22.

Terrell, T. D. (1991). The role of grammar instruction in a communicative approach. The Modern Language Journal, 52-63.

Thornbury, S. (1999). How to teach grammar. Harlow: Longman.

Ur, P. (1988). Grammar practice activities: A practical guide for teachers. Cambridge: Cambridge University Press. 